University of Nebraska - Lincoln

DigitalCommons@University of Nebraska - Lincoln

\title{
Field-to-farm gate greenhouse gas emissions from corn stover production in the Midwestern U.S.
}

C. Rebecca Locker

Corporate Strategic Research

Sarah Torkamani

Corporate Strategic Research

Ian J. Laurenzi

Corporate Strategic Research, ian.j.laurenzi@exxonmobil.com

Virginia L. Jin

USDA-ARS, Lincoln, NE, virginia.jin@ars.usda.gov

Marty Schmer

USDA, marty.schmer@ars.usda.gov

See next page for additional authors

Follow this and additional works at: https://digitalcommons.unl.edu/usdaarsfacpub

Locker, C. Rebecca; Torkamani, Sarah; Laurenzi, Ian J.; Jin, Virginia L.; Schmer, Marty; and Karlen, Douglas L., "Field-to-farm gate greenhouse gas emissions from corn stover production in the Midwestern U.S." (2019). Publications from USDA-ARS / UNL Faculty. 2156.

https://digitalcommons.unl.edu/usdaarsfacpub/2156

This Article is brought to you for free and open access by the U.S. Department of Agriculture: Agricultural Research Service, Lincoln, Nebraska at DigitalCommons@University of Nebraska - Lincoln. It has been accepted for inclusion in Publications from USDA-ARS / UNL Faculty by an authorized administrator of DigitalCommons@University of Nebraska - Lincoln. 


\section{Authors}

C. Rebecca Locker, Sarah Torkamani, Ian J. Laurenzi, Virginia L. Jin, Marty Schmer, and Douglas L. Karlen 


\title{
Field-to-farm gate greenhouse gas emissions from corn stover production in the Midwestern U.S.
}

\author{
C. Rebecca Locker ${ }^{\text {a }}$, Sarah Torkamani ${ }^{\text {a }}$, Ian J. Laurenzi ${ }^{\text {a, }}{ }^{*}$, Virginia L. Jin ${ }^{\text {b }}$, \\ Marty R. Schmer ${ }^{\mathrm{b}}$, Douglas L. Karlen ${ }^{\mathrm{c}}$ \\ ${ }^{a}$ ExxonMobil Research and Engineering Company, Corporate Strategic Research, 1545 Route 22E, Annandale NJ, 08801, USA \\ b USDA-Agricultural Research Service (ARS), 251 Filley/Food Industry Complex, University of Nebraska-Lincoln East Campus, Lincoln, NE, 68583, USA \\ ${ }^{\mathrm{c}}$ USDA-Agricultural Research Service (ARS) National Laboratory for Agriculture and the Environment (NLAE), 1015 N. University Blvd., Ames, IA, 50011- \\ 3611, USA
}

\section{A R T I C L E I N F O}

\section{Article history:}

Received 11 September 2018

Received in revised form

28 February 2019

Accepted 13 March 2019

Available online 28 March 2019

\section{Keywords:}

Life-cycle assessment

Corn stover

Greenhouse gases

Bioenergy

Biofuel

\begin{abstract}
A B S T R A C T
Measured field data were used to compare two allocation methods on life cycle greenhouse gas emissions from corn (Zea mays L.) stover production in the Midwest U.S. We used publicly-available crop yield, nitrogen fertilizer, and direct soil nitrous oxide emissions data from the USDA-ARS Resilient Economic Agricultural Practices research program. Field data were aggregated from 9 locations across 26 site-years for 3 stover harvest rates (no removal; moderate removal $-3.1 \mathrm{Mg} \mathrm{ha}^{-1}$; high removal 7.2 $\mathrm{Mg} \mathrm{ha}^{-1}$ ) and 2 tillage practices (conventional; reduced/no-till). Net carbon uptake by crops was computed from measured plant carbon content. Monte Carlo simulations sampled input distributions to assess variability in farm-to-gate GHG emissions. The base analysis assumed no change in soil organic carbon stocks. In all cases, net $\mathrm{CO}_{2}$ uptake during crop growth and soil-respired $\mathrm{CO}_{2}$ dominated system emissions. Emissions were most sensitive to co-product accounting method, with system expansion emissions $\sim 15 \%$ lower than mass allocation. Regardless of accounting method, lowest emissions occurred for a moderate removal rate under reduced/no-till management. The absence of correlations between $\mathrm{N}$ fertilization rate and stover removal rate or soil $\mathrm{N}_{2} \mathrm{O}$ emissions in this study challenges the use of such assumptions typically employed in life cycle assessments Storage of all carbon retained on the field as SOC could reduce emissions by an additional 15\%. Our results highlight how variability in GHG emissions due to location and weather can overshadow the impact of farm management practices on field-to-farm gate emissions.
\end{abstract}

(c) 2019 Published by Elsevier Ltd.

\section{Introduction}

Renewable energy, such as cellulosic biofuels, is expected to play a significant role in limiting global warming and developing a globally sustainable low-carbon economy (IPCC, 2013). The U.S. Environmental Protection Agency (USEPA) designates cellulosic biofuel pathways as those that achieve at least a $60 \%$ lifecycle greenhouse gas (GHG) reduction from the 2005 petroleum fuel baseline, which amounts to an overall GHG emission of $37.5 \mathrm{~g} \mathrm{CO}_{2}$ eq $\mathrm{MJ}^{-1}$ fuel (US Environmental Protection Agency, 2016). In the U.S., corn stover is an attractive second generation biofuel feedstock because it is widely available, low-cost, and amenable to conversion

\footnotetext{
* Corresponding author.

E-mail address: ian.j.laurenzi@exxonmobil.com (I.J. Laurenzi).
}

to ethanol. Because corn stover plays an important role in erosion protection and maintaining soil fertility (Wilhelm et al., 2007; Johnson et al., 2014), however, partial removal of stover from less erosion-prone areas could be used to meet bioenergy feedstock demands while continuing to provide critical ecosystem services (Karlen et al., 2014; Wortmann et al., 2016). Further, system GHG emissions from stover-based biofuel have been estimated to be lower than conventional transportation fuels (Wang et al., 2012). Whether this meets the USEPA threshold for cellulosic biofuels, however, will depend on the GHG emissions at every stage of biofuel production, including field production of the cellulosic crop, biorefinery processes, and vehicular fuel combustion.

In most corn stover ethanol pathways today, stover is converted to ethanol via enzymatic hydrolysis and fermentation. The US Environmental Protection Agency (2010) reports lifecycle well-towheels (WTW) GHG emissions of $-28.5 \mathrm{~g} \mathrm{CO}_{2}$ eq $\mathrm{MJ}^{-1} \mathrm{EtOH}$ 


\begin{tabular}{|ll|}
\hline Abbreviations \\
GHG & Greenhouse gas \\
$\mathrm{N}_{2} \mathrm{O}$ & Nitrous oxide \\
USDA-ARS & United States Department of Agriculture- \\
& Agricultural Research Service \\
REAP & Resilient Economic Agricultural Practices \\
SOC & Soil organic carbon \\
LCA & Life cycle assessment \\
N & Nitrogen \\
CH & Methane \\
WTW & Wheel-to-well \\
EtOH & Ethanol \\
USEPA & United States Environmental Protection Agency \\
GWP & Global warming potential \\
NRR & No residue removal \\
MRR & Moderate residue removal \\
HRR & High residue removal \\
CON & Conventional tillage \\
ALT & Alternative tillage \\
\hline
\end{tabular}

produced from stover fermentation. Of this WTW total, $1.4 \mathrm{~g} \mathrm{CO}_{2}$ eq $\mathrm{MJ}^{-1}$ EtOH is emitted during the corn stover production stage. However, corn stover production GHG emissions can vary significantly due to weather, location, and LCA method used to account for the corn grain co-product. Using the system expansion accounting method for eight counties in the U.S. Corn Belt, McKechnie et al. (2015) reported positive GHG emissions for seven counties (12.7 $\mathrm{g} \mathrm{CO}_{2}$ eq $\left.\mathrm{MJ}^{-1} \mathrm{EtOH}\right)$ and negative emissions for one county $\left(-5.7 \mathrm{~g} \mathrm{CO}_{2}\right.$ eq $\left.\mathrm{MJ}^{-1} \mathrm{EtOH}\right)$. Other studies using marginal allocation accounting methods show that emissions from the corn stover production may be as high as $26 \mathrm{~g} \mathrm{CO}_{2}$ eq $\mathrm{MJ}^{-1} \mathrm{EtOH}$ (including the carbon footprint of stover transportation from farm to biorefinery) (Canter, et al., 2016) or as low as $-29 \mathrm{~g} \mathrm{CO}_{2}$ eq $\mathrm{MJ}^{-1} \mathrm{EtOH}$ when including direct SOC storage and integrated pathways for cellulosic and grain-based biofuel conversion (Schmer et al., 2014b).

Outcomes of LCAs such as those referenced here depend on modeled GHG data, which often do not capture the variability in emissions at the corn field due to weather, geography, soil type, and farm management practices (Jin et al., 2014). One main goal of the current study is to resolve these disparate values by providing a statistical distribution of GHG emissions across the U.S. Corn Belt rather than reporting discrete values from specific locations. To accomplish this, we utilize two unique approaches to this LCA. First, instead of using modeled GHG emissions, our statistical distributions of GHG emissions were based on measured grain and biomass yields, management data, and soil GHG emissions from nine sites located in the U.S. Corn Belt which all used a standardized experimental field design as part of the USDA-ARS Resilient Economic Agricultural Practices (REAP) program (Del Grosso et al., 2014). The selected locations were distributed across the U.S. Corn Belt, thus capturing the geographic variability across this region. Second, we explicitly address biogenic carbon by quantifying the variability in net primary productivity within the U.S. Corn Belt unlike previous studies (Qin et al., 2018; Zhang and Kendall, 2017; Zhao, Ou and Y 2016; Gerbrandt et al., 2016; McKechnie et al., 2015; US Environmental Protection Agency, 2010), by accounting for the carbon taken up by the corn plant through photosynthesis. Because much of this carbon is then stored in the corn grain and stover products at the farm gate, the field-to-farm gate emissions are negative. Within a full WTW assessment of a corn stover product such as cellulosic ethanol, the carbon stored in the stover would eventually be emitted either at the biorefinery or through end use combustion in the vehicle. A WTW assessment of corn stover ethanol using this approach will be presented in a forthcoming publication.

Our novel use of measured field data and explicit accounting for carbon flows allow us to conduct a robust system expansion methodology to compare against the typical mass allocation accounting method, where Monte Carlo (MC) simulations are used to compute the GHG emissions from measured input distributions. Although our findings suggest that sensitivity to co-product accounting method can impact system GHG emissions as much as $15 \%$, site-specific variability due to soils and weather can overshadow GHG impacts of agronomic management. Regardless, the field-to-farm gate analysis here is intended as a modular result for corn stover production emissions that can be applied for use in LCAs that utilize corn stover as a feedstock.

\section{Methods}

\subsection{LCA methods}

\subsubsection{System boundaries and scenarios}

Greenhouse gas (GHG) emissions are reported in $\mathrm{CO}_{2}$ equivalents, representing emissions from carbon dioxide $\left(\mathrm{CO}_{2}\right)$, nitrous oxide $\left(\mathrm{N}_{2} \mathrm{O}\right)$, and methane $\left(\mathrm{CH}_{4}\right)$. Emission sources are evaluated and weighted using 100-year global warming potentials (GWPs) from the 5th Assessment of the International Panel on Climate Change (IPCC 2013). For this study, we consider fields where corn grain and stover are co-produced; currently, stover is often left on the soil surface or incorporated back into the soil. To account for the GHG emissions associated with producing corn grain and corn stover, all results are reported per unit mass of the products. This allows for an evaluation that is independent of potential further processing as feed, fuel or chemicals.

The system boundaries for computing the field-to-farm gate GHG emissions of corn grain and corn stover are depicted in grain and stover production data (reported on a dry matter basis) aggregated by farm management practice and stover removal rate. The six farm management scenarios considered here are representative of common producer practices and were the standard experimental treatments used at USDA-ARS REAP sites (Jin et al., 2014; Johnson et al., 2014; Karlen et al., 2014):

1. No stover removal, with conventional tillage (NRR|CON),

2. No stover removal, with alternative (conservation) tillage (NRR|ALT),

3. Moderate stover removal, with conventional tillage (MRR $\mid \mathrm{CON})$, 4. Moderate stover removal, with alternative tillage (MRR $\mid$ ALT),

5. High stover removal, with conventional tillage (HRR|CON), and

6. High stover removal, with alternative tillage (HRR|ALT).

The moderate and high stover removal rates are equivalent to 3.1 $\mathrm{Mg} \mathrm{ha}^{-1}$ and $7.2 \mathrm{Mg} \mathrm{ha}^{-1}$, respectively (see 2.2 Agricultural Inventory).

System GHG emissions contributions from each production stage are included so that:

$\Delta_{t} \boldsymbol{G}_{\boldsymbol{E}}=\Delta_{\boldsymbol{t}} \boldsymbol{G}_{\boldsymbol{F}}+\Delta_{\boldsymbol{t}} \boldsymbol{G}_{\boldsymbol{N}}+\Delta_{\boldsymbol{t}} \boldsymbol{G}_{\boldsymbol{O}}+\Delta_{\boldsymbol{t}} \boldsymbol{G}_{\boldsymbol{C}}+\Delta_{\boldsymbol{t}} \boldsymbol{G}_{\boldsymbol{H}}+\Delta_{\boldsymbol{t}} \boldsymbol{G}_{\boldsymbol{B}}$

where the total GHG emissions $\left(\boldsymbol{G}_{\boldsymbol{E}}\right)$ is the sum of emissions due to fertilizer production, transport and application $\left(\boldsymbol{G}_{\boldsymbol{F}}\right)$, soil $\mathrm{N}_{2} \mathrm{O}$ emissions $\left(\boldsymbol{G}_{\boldsymbol{N}}\right)$, field operations $\left(\boldsymbol{G}_{\boldsymbol{O}}\right)$, net agricultural ecosystem carbon emissions $\left(\boldsymbol{G}_{\boldsymbol{C}}\right)$, corn harvesting $\left(\boldsymbol{G}_{\boldsymbol{H}}\right)$, and stover harvesting and baling operations $\left(\boldsymbol{G}_{\boldsymbol{B}}\right)$. Fig. 1a illustrates the two management cases where stover is left on the field (NRR|CON, NRR|ALT). Fig. 1b 

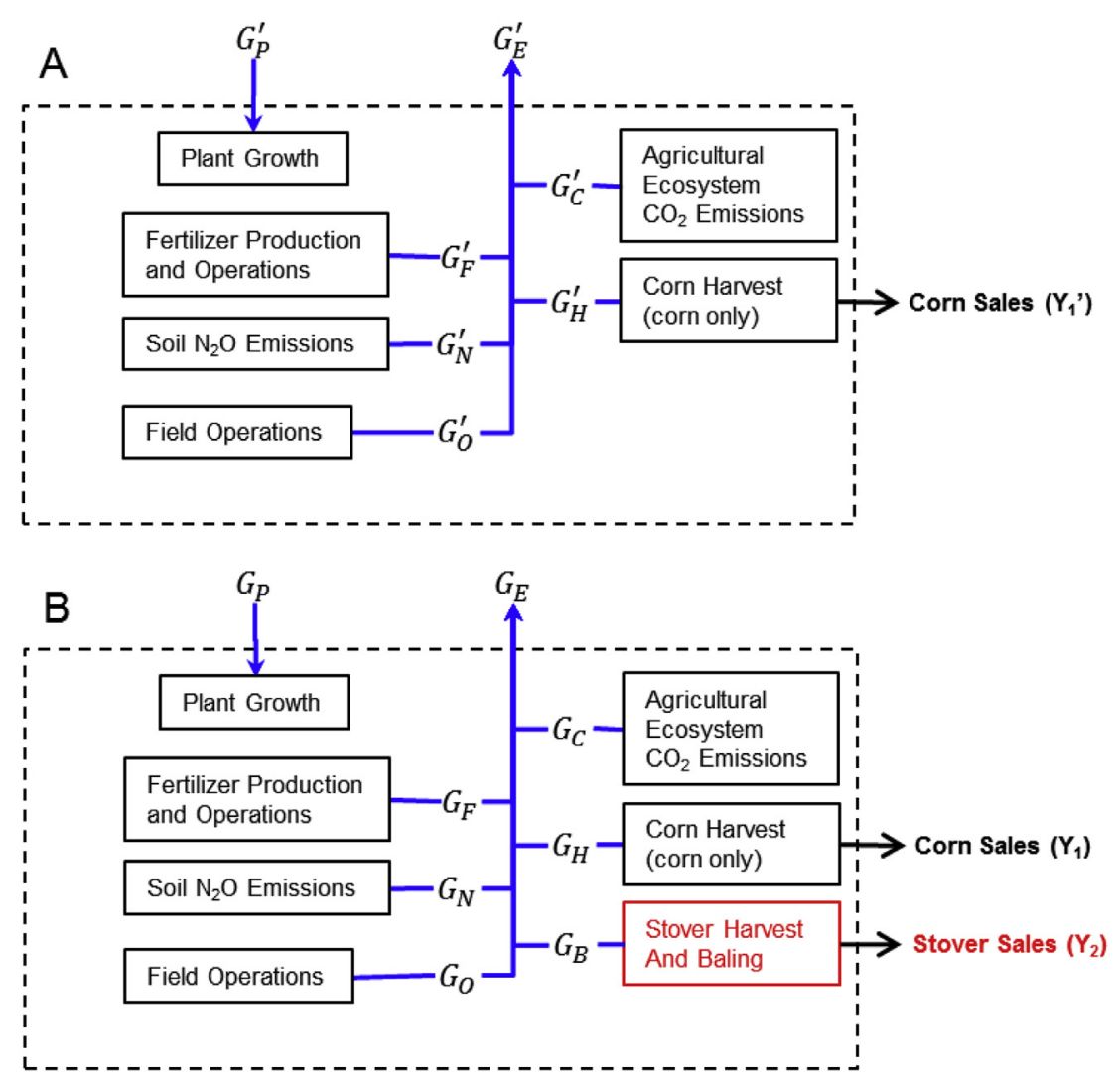

Fig. 1. System boundaries for field-to-farm gate GHG emissions of (A) corn grain-only production [denoted by (')], and (B) corn grain + corn stover production.

illustrates the four management cases where stover is partially removed as a co-product (MRR $\mid$ CON, MRR $\mid$ ALT, HRR $\mid$ CON, HRR $\mid$ ALT).

The net agricultural ecosystem carbon emissions are computed as the sum of emissions from biomass degradation on the field $\left(\boldsymbol{G}_{\boldsymbol{D}}\right)$ and from changes in soil organic carbon stocks ( $\left.\boldsymbol{G}_{S O C}\right)$ :

$\Delta_{t} G_{C}=\Delta_{t} G_{D}+\Delta_{t} G_{S O C}$

For this field-to-farm gate study, carbon in the products (grain, stover) is stored in the product at the farm gate rather than emitted if we were considering end use. Operational emissions include tillage, planting, herbicide production and application, and grain transport to roadside. Seed production emissions are assumed negligible, and emissions from irrigation are omitted because most sites were rainfed. The net GHG emissions for the entire production process is given as:

$\Delta_{t} \boldsymbol{G}=\Delta_{t} \boldsymbol{G}_{E}+\Delta_{t} \boldsymbol{G}_{P}$

where $\Delta_{t} G_{P}$ is the $\mathrm{CO}_{2}$ removed from the atmosphere and stored in the plant via photosynthesis. This value is necessarily negative.

The time dependence for the terms in Eqns. (1)-(3) is depicted as $\Delta_{t} x=x_{t_{f}}-x_{t_{i}}$. In this work, we report $\Delta_{t} G$ as annual emissions across a 30 year production period (i.e., $t_{f}-t_{i}=30 \mathrm{yr}$ ). Annual emissions occurring throughout this period (i.e., $\Delta_{t} G_{F}, \Delta_{t} G_{N}, \Delta_{t} G_{O}$, $\left.\Delta_{t} G_{H}, \Delta_{t} G_{B}, \Delta_{t} G_{D}, \Delta_{\downarrow} t G_{\downarrow} p\right)$ are computed by sampling from distributions of USDA-ARS REAP field-measured values (see 2.2 Agricultural Inventory). We assume similar distributions of annual emissions from the field during sampling period $(2-5 \mathrm{yr})$ and the $30 \mathrm{yr}$ production period.

For the grain-only production (Fig. 1a), net GHG emissions are:
$B^{\prime}=\Delta_{t} G^{\prime} / \Delta_{t} Y 1^{\prime}$

where $B^{\prime}$ is the lifecycle GHG emissions associated with grain production ( $\mathrm{kg} \mathrm{CO}_{2}$ eq kg ${ }^{-1}$ grain), $\Delta_{t} G^{\prime}$ is the annual GHG emissions from corn grain production including fertilizer production, field operations, soil emissions, and harvesting $\left(\mathrm{kg} \mathrm{CO}_{2}\right.$ eq ha $\left.{ }^{-1}\right)$ across the $30 \mathrm{yr}$ production period, and $\Delta_{t} Y 1^{\prime}$ is the annual grain yield ( $\mathrm{kg}_{\text {grain }} \mathrm{ha}^{-1}$ ) across the $30 \mathrm{yr}$ production period. We assume $100 \%$ of the grain produced goes to sales, as in Fig. 1.

\subsubsection{Marginal allocation vs. system expansion}

When corn stover is a co-product, GHG emissions must be partitioned to both grain and stover (Fig. 1b). The International Standards Organization (ISO) provides standards and a LCA methodological framework under ISO 14040 (International Standards Organization (ISO) 2006). Two methods are recommended for attributing environmental impacts to two or more co-products: allocation and system expansion. ISO 14040 recommends using the system expansion approach when possible, but allocation is also appropriate when products are co-produced in the majority of production operations (i.e. when stover is co-harvested on the majority of corn acreage). Moreover, in the context of stoverderived biofuels, it has recently been argued that the allocation approach is methodologically inconsistent with consequential LCA and accounting for land use change (Sanchez et al., 2012).

In the allocation method, GHG emissions associated with production of both materials are allocated to each product based on their relative masses, energy contents, or economic values. When allocating by mass between grain and stover, GHG emissions associated with stover are: 
$B_{A}=\frac{\Delta_{t} G}{\Delta_{t} Y 2} * \frac{\Delta_{t} Y 2}{\Delta_{t} Y 1+\Delta_{t} Y 2}$

where $B_{A}$ is the GHG emissions allocated to stover production ( $\mathrm{kg}$ $\mathrm{CO}_{2}$ eq $\mathrm{kg}^{-1}$ stover harvested), $\Delta_{t} G$ is the annual GHG emissions from co-produced grain and stover $\left(\mathrm{kg} \mathrm{CO}_{2}\right.$ eq ha $\left.{ }^{-1}\right), \Delta_{t} Y 1$ is the annual grain yield $\left(\mathrm{kg}\right.$ grain ha $\left.{ }^{-1}\right)$, and $\Delta_{t} Y 2$ is the annual stover yield ( $\mathrm{kg}$ stover harvested $\mathrm{ha}^{-1}$ ) over the $30 \mathrm{yr}$ production period. All grain and stover yields are reported on a dry matter basis. The USDA-ARS REAP dataset compiled in this work is sufficient for computation of mass-allocated LCA of corn stover production in the U.S. Corn Belt.

In the system expansion method, the grain-only production system serves as a reference for a system where both grain and stover are produced. Thus, the GHG emissions associated with stover production $\left(B_{S E}, \mathrm{~kg} \mathrm{CO}_{2}\right.$ eq $\mathrm{kg}^{-1}$ stover harvested) using system expansion is:

$$
\begin{aligned}
\boldsymbol{B}_{\boldsymbol{S E}} & =\left[\frac{\Delta_{t} \boldsymbol{G}}{\Delta_{\boldsymbol{t}} \boldsymbol{Y} 1}-\frac{\Delta_{t} \boldsymbol{G}^{\prime}}{\Delta_{\boldsymbol{t}} \boldsymbol{Y} 1^{\prime}}\right]\left[\frac{\Delta_{t} \boldsymbol{Y} 1}{\Delta_{\boldsymbol{t}} \boldsymbol{Y} 2}\right] \\
& =\Delta_{\sigma}\left[\frac{\Delta_{t} \boldsymbol{G}}{\Delta_{\boldsymbol{t}} \boldsymbol{Y} 1}\right]\left[\frac{\Delta_{t} \boldsymbol{Y} 1}{\Delta_{t} Y 2}\right] \equiv \Delta_{\sigma} \Delta_{t}\left(\frac{\boldsymbol{G}}{\boldsymbol{Y} 1}\right)\left[\frac{\Delta_{t} \boldsymbol{Y} 1}{\Delta_{t} Y 2}\right]
\end{aligned}
$$

where the "prime" (') denotes the grain-only reference system (Fig. 1a). The emissions difference between the reference system (grain-only production) and the system of interest (grain and stover production) over time is denoted as $\Delta_{\sigma} \boldsymbol{x}=\boldsymbol{x}-\boldsymbol{x}^{\prime}$. In other words, the emissions are computed as a "delta delta." The system expansion method in Eqn. (6) requires inventory for both reference and stover removal systems. The USDA-ARS REAP dataset provides $Y 1$, $Y 2$ and $Y 1$ ' and components for computing $G$ and $G$ '. For data for each management case, see 2.2 Agricultural Inventory.

Most LCA approaches for corn stover production or stoverderived biofuels, including those used by the IPCC and Argonne National Laboratory's (2014) Greenhouse Gases, Regulated Emissions, and Energy Use in Transportation (GREET) model, employ a "marginal" or "differential" approach to allocate emissions to stover (Wang et al., 2012). This approach is based on system expansion with further simplifying assumptions (Table 1). The marginal method assumes the same grain yields in the stover production vs grain-only reference systems, reducing Eqn. (4) to:

$\boldsymbol{B}=\left(\boldsymbol{G}-\boldsymbol{G}^{\prime}\right) / \mathbf{Y} 2$

In system expansion, corn yields for the two systems are included explicitly, where emissions are normalized by grain yield for each system before reference emissions are subtracted. The marginal method further assumes that nitrogen $(\mathrm{N})$, phosphorous (P) and potassium (K) removed during stover harvest will be replaced by fertilizer application. We make this simplifying assumption for $\mathrm{P}$ and $\mathrm{K}$ because their production contributes $<1 \%$ to the overall GHG emissions (vide infra). For $\mathrm{N}$, however, we use system expansion with USDA-ARS REAP fertilizer $\mathrm{N}$ rates to explicitly account for the GHG emissions associated with $\mathrm{N}$ fertilizer production.

The marginal method assumes corn harvesting and tillage GHG emissions are identical in the grain-only reference system and stover production systems. Further, the marginal method assumes that soil $\mathrm{N}_{2} \mathrm{O}$ emissions are the product of the volatilization rate of $\mathrm{N}$ fertilizer and the $\mathrm{N}$ fertilization rate distributions, which in GREET are based on literature-reported values of soil emissions and fertilization rates from 1978 to 2010. In this context, the "volatilization rate" is the rate that $\mathrm{N}$ fertilizer is transformed to $\mathrm{N}_{2} \mathrm{O}$. In contrast, we use harvesting and tillage emissions and soil $\mathrm{N}_{2} \mathrm{O}$ emissions reported explicitly for each farm management case herein to compute emissions with system expansion. Finally, both methods allocate all of the stover harvest and baling emissions to the stover product.

\subsubsection{GHG distributions and statistical analyses}

We compare system emissions distributions based on GREETmodeled data and field data using MC simulations of 5,000 trials each. Oracle ${ }^{\circledR}$ Crystal Ball (Oracle Crystal Ball, 2008) was used to conduct MC simulations of total GHG emissions associated with corn grain and stover production. Where possible, each input variable was modeled as a distribution rather than a static parameter. A total of 56 input distributions ("assumption variables") were sampled for each MC trial. The mean, standard error and sample sizes of USDA-ARS REAP data were used to parameterize the inputs as log-normally distributed variables for most inputs. Percentages

Table 1

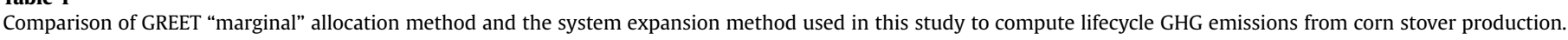

\begin{tabular}{|lllll|}
\hline Term by stage & Marginal Method & Marginal Term & System Expansion & System Expansion Term \\
\hline $\begin{array}{l}\text { Corn stover } \\
\text { emissions, } B\end{array}$ & $\begin{array}{l}\text { Corn yield equal } \\
\text { in both systems }\end{array}$ & $B=\frac{\Delta_{\sigma} \Delta_{t} G}{\Delta_{t} Y 2}$ & $\begin{array}{l}\text { Measured for both } \\
\text { systems }\end{array}$ & $B=\Delta_{\sigma} \Delta_{t}\left(\frac{G}{Y 1}\right)\left(\frac{\Delta_{t} Y 1}{\Delta_{t} Y 2}\right)$ \\
\hline $\begin{array}{l}\text { Fertilizer } \\
\text { production, } B_{F}\end{array}$ & $\begin{array}{l}\text { Nutrients in stover } \\
\text { replaced by mass }\end{array}$ & $B_{F}=\frac{\Delta_{\sigma} \Delta_{t} G_{F}}{\Delta_{t} Y 2}$ & $\begin{array}{l}\text { Use recorded for } \\
\text { both systems }\end{array}$ & $B_{F}=\Delta_{\sigma} \Delta_{t}\left(\frac{G_{F}}{Y 1}\right)\left(\frac{\Delta_{t} Y 1}{\Delta_{t} Y 2}\right)$ \\
\hline $\begin{array}{l}\text { Soil N } \mathrm{N}_{2} \mathrm{O} \\
\text { emissions, } B_{N}\end{array}$ & $\begin{array}{l}\text { Proportional to } \\
\text { fertilization rate }\end{array}$ & $B_{N}=\frac{\Delta_{\sigma} \Delta_{t} G_{N}}{\Delta_{t} Y 2}$ & $\begin{array}{l}\text { Measured for both } \\
\text { systems }\end{array}$ & $B_{N}=\Delta_{\sigma} \Delta_{t}\left(\frac{G_{N}}{Y 1}\right)\left(\frac{\Delta_{t} Y 1}{\Delta_{t} Y 2}\right)$ \\
\hline $\begin{array}{l}\text { Field operations, } \\
B_{O}\end{array}$ & $\begin{array}{l}\text { Same for both } \\
\text { systems }\end{array}$ & $B_{O}=0$ & $\begin{array}{l}\text { Recorded for both } \\
\text { systems }\end{array}$ & $B_{O}=\Delta_{\sigma} \Delta_{t}\left(\frac{G_{O}}{Y 1}\right)\left(\frac{\Delta_{t} Y 1}{\Delta_{t} Y 2}\right)$ \\
\hline $\begin{array}{l}\text { Agricultural } \\
\text { ecosystem CO } \\
\text { emissions, } B_{C}\end{array}$ & $\begin{array}{l}\text { Assumed biogenic } \\
\text { C balance }\end{array}$ & $\mathrm{N} / \mathrm{A}$ & $\begin{array}{l}\text { Computed for } \\
\text { both systems }\end{array}$ & $B_{C}=\Delta_{\sigma} \Delta_{t}\left(\frac{G_{C}}{Y 1}\right)\left(\frac{\Delta_{t} Y 1}{\Delta_{t} Y 2}\right)$ \\
\hline Corn harvest, $B_{H}$ & $\begin{array}{l}\text { Corn harvest } \\
\text { operations 100\% } \\
\text { allocated to corn }\end{array}$ & $B_{H}=0$ & $\begin{array}{l}\text { Based on reported } \\
\text { corn yields for } \\
\text { each system }\end{array}$ & $B_{H}=\Delta_{\sigma} \Delta_{t}\left(\frac{G_{H}}{Y 1}\right)\left(\frac{\Delta_{t} Y 1}{\Delta_{t} Y 2}\right)$ \\
\hline $\begin{array}{l}\text { Stover harvest } \\
\text { and bale, } B_{B}\end{array}$ & $\begin{array}{l}100 \% \text { allocated to } \\
\text { stover }\end{array}$ & $B_{B}=\frac{\Delta_{t} G_{B}}{\Delta_{t} Y 2}$ & $\begin{array}{l}100 \% \text { allocated to } \\
\text { stover }\end{array}$ & $B_{B}=\frac{\Delta_{t} G_{B}}{\Delta_{t} Y 2}$ \\
\hline
\end{tabular}


and fractions were modeled as Beta distributions. Unless otherwise noted, 5,000 MC trials were conducted to create a distribution of GHG emissions and to compute a converged mean value of the GHG emissions associated with corn stover. Two-tailed T-tests were performed on all parameters based on experimentally-measured data to determine whether expectation values (means) were nonzero. Means were statistically nonzero for all parameters except the yearly $\mathrm{CH}_{4}$ emissions attributed to the growing season (Table A4). In this case, the null hypothesis (no $\mathrm{CH}_{4}$ emissions attributed to the growing season) could not be disproven $(\mathrm{p}<0.05)$, so direct soil $\mathrm{CH}_{4}$ emissions were omitted in all subsequent calculations.

\subsection{Agricultural inventory}

The agricultural inventory detailed in the appendix comprises all the data required to compute the GHG emissions for each stage in crop production. Briefly, at each site, stover was retained on a portion of the field as the reference state (no removal rate, NRR), and stover was removed at one or two rates: moderate removal rate (MRR) with $30-35 \%$ of the stover removed, and high removal rate (HRR) with $68-73 \%$ of the stover removed. Tillage practices were grouped into two categories: conventional tillage (CON) and alternative conservation tillage (ALT), which includes reduced tillage and no-till practices. The nine locations, farm management, and years of data collection, are obtained from Jin et al. (2014) (Table A1). Since each site did not practice all combinations of stover removal rates and tillage methods, we do not attempt to disaggregate our results by location or year of data collection.

We did not attempt to disaggregate by crop rotation type. Although corn-soybean (Glycine max (L.) Merr.) rotations are common throughout the U.S. Corn Belt, increasing market opportunities for corn grain ethanol has led to significant increases in corn acreage in many states (USDA ERS, 2016). Demand for stover feedstock will likely continue this trend toward continuous corn production (Archer and Johnson, 2012). Stover removal at one northern Corn Belt site increased soil $\mathrm{N}_{2} \mathrm{O}$ emissions during the soybean rotation by $\sim 30 \%$ compared to no stover removal (Lehman and Osborne, 2016), but the generality of this finding is unknown and outside the scope this work. Here, the annual GHG emissions are averaged across 6 sites under continuous corn production and the corn-phase only for 3 sites under corn-soybean rotation.

At each site, commercial-scale farm equipment was used, representing current corn production practices. Most U.S. corn production in the Corn Belt is non-irrigated (USDA ERS, 2016), which is reflected in only two of nine sites applying supplemental irrigation. At all sites, data were collected at least one year after implementing the farm management plan. Average corn yields ranged from 9.5 to $10.8 \mathrm{Mg} \mathrm{ha}^{-1}$, consistent with 10-yr U.S. average grain yields (9.4-10.5 $\mathrm{Mg} \mathrm{ha}^{-1}$ ) (USDA ERS, 2016). Thus, the GHG emissions computed here for corn grain and stover production are expected to be representative of typical commercial-scale production scenarios.

\subsubsection{Yields, fertilization rates, and soil $\mathrm{N}_{2} \mathrm{O}$ emissions}

Yields, stover removal rates, $\mathrm{N}$ fertilization rates, and soil emissions were aggregated from the nine USDA-ARS REAP field sites. The two grain-only reference scenarios are NRR $\mid C O N$ and NRR|ALT (Table A2), and four grain and stover production scenarios are MRR|CON, MRR|ALT, HRR|CON, and HRR|ALT (Table A3). Sitespecific grain yield, stover removal rate, stover yield, and $\mathrm{N}$ fertilization rates from a previous report (Karlen et al., 2014) were aggregated to obtain a complete lifecycle inventory of the nine sites, including soil emissions data (Jin et al., 2014). Corn grain and stover yields, $\mathrm{N}$ fertilization rates, and soil $\mathrm{N}_{2} \mathrm{O}$ emissions were averaged spatially and temporally for each scenario to reporting mean, standard error, and sample size ( $\mathrm{n}=$ total site-years).

Soil $\mathrm{CH}_{4}, \mathrm{~N}_{2} \mathrm{O}$ and $\mathrm{CO}_{2}$ fluxes over the crop growing season were measured from static vented chambers, as described in Jin et al. (2014). Soil $\mathrm{CH}_{4}$ fluxes were negligible and were not included here. Methods to compute total $\mathrm{CO}_{2}$ soil emissions is described below (see 2.2.3). Annual soil emission rates were calculated by dividing growing season emissions by the fraction of annual emissions attributed to the growing season (Table A4), and used to compute $\Delta_{\boldsymbol{t}} \boldsymbol{G}_{\boldsymbol{N}}$ (Eqn. (1)).

\subsubsection{Plant growth}

The net $\mathrm{CO}_{2}$ uptake from the atmosphere by the plant due to photosynthesis is computed based on the measured carbon content of the corn grain, stover, and roots (Table A8). Distributions in carbon content of grain and stover were obtained from field data and averaged over the collection period. Belowground carbon content ranges from $33 \%$ to $114 \%$ of the aboveground carbon, depending on inclusion of rhizodeposit-carbon (Johnson et al., 2006). These values defined the minimum and maximum distribution of belowground plant carbon content, respectively. Stover biomass and carbon content is calculated using harvest index (i.e. grain-to-total biomass ratio) provided in the USDA-ARS REAP data (Table A3), then used to compute $\Delta_{\boldsymbol{t}} \boldsymbol{G}_{\boldsymbol{P}}$ in Eqn. (3).

\subsubsection{Agricultural ecosystem $\mathrm{CO}_{2}$ emissions}

Here we assume that enough time has passed since adoption of management changes and best practices for stover harvest for SOC to reach steady-state, which reduces Eqn. (2) to

$$
\Delta_{t} \boldsymbol{G}_{C}=\Delta_{t} \boldsymbol{G}_{D}
$$

Jin et al. (2014) reported that $\mathrm{CO}_{2}$ accounts for $>90 \%$ of chamberbased soil GHG emissions in all management cases, where $\mathrm{CO}_{2}$ was a combination of root autotrophic and soil heterotrophic respiration which could not be partitioned. Therefore, to account for all plant carbon emissions from the field, our base analyses represents net agricultural ecosystem $\mathrm{CO}_{2}$ emissions using Eqn. (8) instead of using the field $\mathrm{CO}_{2}$ measurements. Under steady-state conditions, the annual emissions due to biomass degradation is computed by subtracting the carbon content of the grain and stover products from the net primary productivity. This assumes that carbon inputs from roots and stover on the soil surface is totally offset by soil respiration, resulting in no net SOC change.

To assess how SOC changes under non-steady state farming conditions affect system GHG emissions, we compute potential SOC change as equivalent to all carbon remaining on the field retained as SOC during the first $5 \mathrm{yr}$ of production and amortized over the $30 \mathrm{yr}$ production period. While some empirical studies have shown that SOC changes can take several years to detect following management changes (Follett et al., 2012; Johnson et al., 2014; Lehman and Osborne, 2016), others report that shorter-term SOC changes can occur (Clay et al., 2015). We acknowledge that the actual storage capacity of the soil is likely lower than our assumption and will depend on the baseline SOC, biomass composition, soil type, and environmental conditions (Castellano et al., 2015). However, the scenario here represents a theoretical upper bound for maximum SOC storage $\left(\Delta_{\boldsymbol{t}} \boldsymbol{G}_{\boldsymbol{S O C}}\right)$, such that the carbon stored in the soil for the first 5 years is

$$
\Delta_{t} C_{S O C}=\Delta_{t} C_{P}-\Delta_{t} C_{m e a s u r e d}-\Delta_{t} C_{\text {grain }}-\Delta_{t} C_{\text {harvested stover }}
$$

where $\Delta_{t} C_{S O C}$ is the annual change in SOC, computed as the difference between the carbon stored through net primary productivity $\left(\Delta_{t} C_{P}\right)$ and the chamber-based measure of carbon removed 
from the site as $\mathrm{CO}_{2}\left(\Delta_{t} C_{\text {measured }}\right)$, grain $\left(\Delta_{t} C_{\text {grain }}\right)$, and harvested stover $\left(\Delta_{t} C_{\text {harvested stover }}\right)$.

\subsubsection{Fertilizer production and application}

Chemical fertilizer types and production GHG emissions were obtained from publicly available databases (Tables A5, A6). Chemical fertilizers were grouped into fertilizer classes in order to obtain average GHG emissions of $\mathrm{N}, \mathrm{P}$, and $\mathrm{K}$ fertilizers, weighted by reported consumption. Production and transport emissions for fertilizers were obtained from GREET_2014 (Argonne National Laboratory, 2014), with additional emissions data for $\mathrm{N}$ fertilizer from Ecolnvent 2.2 (Frischknecht et al., 2005). The $\mathrm{N}$ fertilization rate was provided by USDA-ARS REAP field data for each farm management case (Tables A2, A3). The equivalent fertilizer replacement rates for stover $\mathrm{P}$ and $\mathrm{K}$ removed are $2 \mathrm{~kg} \mathrm{P}_{2} \mathrm{O}_{5}$ ton $^{-1}$ stover and $12 \mathrm{~kg} \mathrm{~K}_{2} \mathrm{O}$ ton $^{-1}$ stover (Wang et al., 2012). Application emissions from N, P and $\mathrm{K}$ are based on a fertilizer rate of $198 \mathrm{~kg} \mathrm{~N}$ $\mathrm{ha}^{-1}$, requiring $25.4 \mathrm{~L}_{\text {diesel ha }}{ }^{-1}$ (Iowa State Extension 2010), and used to compute $\Delta_{\boldsymbol{t}} \boldsymbol{G}_{\boldsymbol{F}}$ in Eqn. (1).

\subsubsection{Field and harvesting operations}

Diesel usage for conventional (CON) tillage was computed as the mean of the three tillage types used in the USDA-ARS REAP sites, weighted by the number of site-years for each (moldboard plow $=3$ site-years, chisel plow $=6$ site-years, disk $=2$ site-years) (Jin et al., 2014). Alternative (ALT) tillage diesel usage was computed as the average for strip till and no-till, weighted by the number of site-years for each (strip till $=3$ site-years, no-till $=23$ site-years) (Jin et al., 2014). Fuel emissions and equipment capacities for fertilization, planting, weeding, tillage, harvesting, and collection are reported in Table A7 and used to compute $\Delta_{\boldsymbol{t}} \boldsymbol{G}_{\boldsymbol{O}}$ and $\Delta_{\boldsymbol{t}} \boldsymbol{G}_{\boldsymbol{H}}$ in Eqn. (1).

\section{Results}

\subsection{Crop yield and agricultural $\mathrm{CO}_{2}$ fluxes}

Corn grain yield tended to be higher under CON tillage compared to ALT tillage (Fig. 2b), but was not correlated with stover removal rate or fertilizer $\mathrm{N}$ rate (Fig. $3 \mathrm{~b}$ ). Different distribution shapes reflect the variability of measured quantities across different sites and years.

The proportion of total biomass as grain, however, tended to be highest under the most aggressive stover removal rate, such that plant $\mathrm{CO}_{2}$ uptake per mass of corn grain $\left(\Delta_{\boldsymbol{t}} \boldsymbol{G}_{\boldsymbol{P}}\right.$; Eqn. (3)) is lower for HRR than NRR or MRR (Table 2). Mean agricultural $\mathrm{CO}_{2}$ emissions due to plant biomass decomposition decreases as harvested biomass increases from NRR to MRR to HRR, and are higher under
CON compared to ALT tillage (Table 3).

\subsection{Distributions of annual soil $\mathrm{N}_{2} \mathrm{O}$ emissions}

Data distributions for annual soil $\mathrm{N}_{2} \mathrm{O}$ emissions generated from Monte Carlo (MC) simulations based on USDA-ARS REAP field measurements overlap between all management cases (Fig. 2a), with lowest soil $\mathrm{N}_{2} \mathrm{O}$ emissions from moderate stover removal and under CON tillage. Furthermore, field-based data distributions for NRR $\mid C O N$ (grain-only reference system) were similar to those modeled in GREET (Table 4).

In contrast, MC simulations sampled from field-measured vs GREET-modeled data under stover removal scenarios with best practices (MRR|ALT, HRR|ALT) resulted in sharply contrasting distributions (Fig. 4). Distributions for both stover removal scenarios using system expansion are more Gaussian-shaped (Fig. 4a and b), while the GREET-based distribution is lognormal (Fig. 4c). Only one data distribution is shown for GREET because it considers only one level of stover removal based on literature, which typically report high stover removal rates. As a result, HRR|ALT and GREET mean values are similar $\left(0.04 \mathrm{~kg} \mathrm{CO}_{2}\right.$ eq $\mathrm{kg}^{-1}$ stover $)$. As our distribution is reflective of the system-expansion approach, it is more appropriate for use in consequential LCAs of biofuels generated from corn stover.

\subsection{System GHG emissions from corn stover production}

System GHG emissions for corn stover production (MRR|CON, MRR|ALT, HRR|CON, HRR|ALT) are similar to the base case of grainonly production under CON tillage (NRR|CON) (Supplemental Information, Figure $\mathrm{A} 1$ ). In all scenarios, net emissions are dominated by soil $\mathrm{CO}_{2}$ emissions and net $\mathrm{CO}_{2}$ uptake (Fig. 5), with minor $\mathrm{GHG}$ contributions from soil $\mathrm{N}_{2} \mathrm{O}$ and fertilizer production (Figure A5). Overall, net GHG emissions across stover production systems are not affected by stover removal rate or tillage practice (Figs. 5 and 6). Net emissions, however, are $8 \%-18 \%$ higher using the mass allocation accounting method compared to system expansion, but within one standard deviation of the system expansion results (Figs. 5 and 6).

\subsection{Sensitivity analyses}

Input variables contributing to plant carbon uptake, soil emissions, functional unit (mass of corn) and, to a lesser extent, $\mathrm{N}$ fertilizer production, have large impacts on overall GHG emissions for all farm management cases. To illustrate, we conduct sensitivity analyses using the two different co-product accounting methods on the MRR|ALT case to represent the expected farmer practice for a

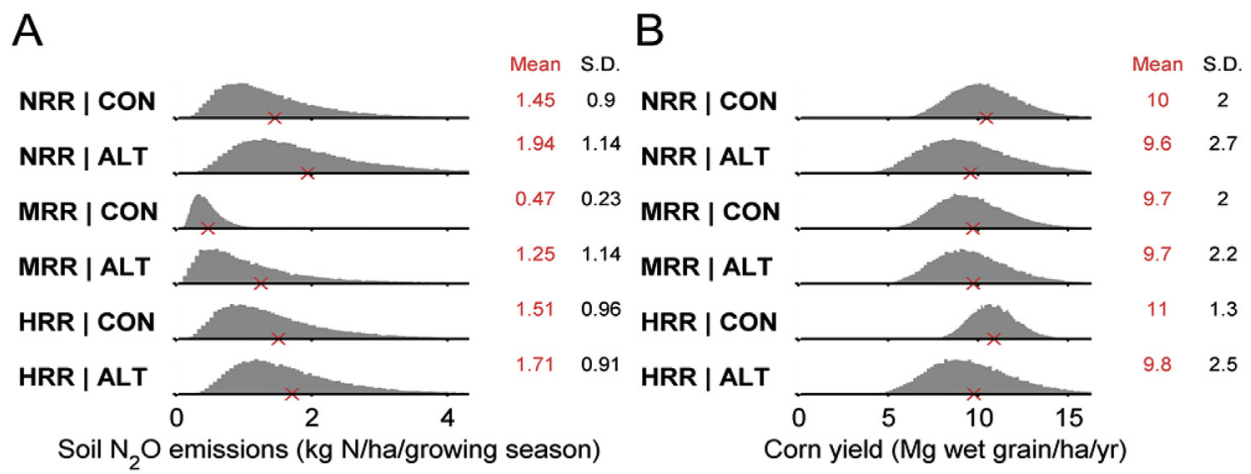

Fig. 2. (a) Soil $\mathrm{N}_{2} \mathrm{O}$ emissions, $\Delta_{t} \boldsymbol{G}_{\boldsymbol{N}}$, and (b) grain yield, Y1, for the six farm management cases. Grain weight is reported at 15.5 wt $\%$ moisture content. 
A

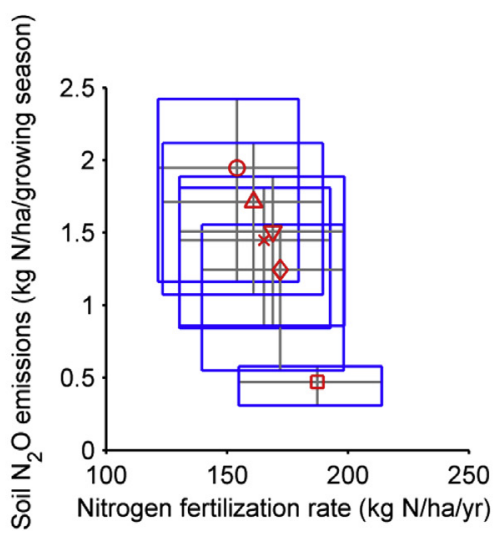

B




percentile in the measured distributions of each parameter.

Table 2

Mean net $\mathrm{CO}_{2}$ uptake during plant growth (net primary productivity, $\Delta_{\mathrm{t}} \mathrm{G}_{\mathrm{p}}$ ) computed from the yields of above and below-ground biomass and their measured carbon content.

\begin{tabular}{|c|c|c|}
\hline \multirow{3}{*}{ Residue Removal Level } & \multicolumn{2}{|l|}{$\Delta_{\mathrm{t}} \mathrm{G}_{\mathrm{P}}$} \\
\hline & CON Tillage & ALT Tillage \\
\hline & \multicolumn{2}{|c|}{$\mathrm{kg} \mathrm{CO}_{2} \mathrm{~kg}^{-1}$ dry corn grain } \\
\hline NRR & -4.7 & -4.7 \\
\hline MRR & -5.1 & -5.0 \\
\hline HRR & -4.5 & -4.4 \\
\hline
\end{tabular}

Table 3

Mean $\mathrm{CO}_{2}$ emissions due to biomass decomposition on the field $\left(\Delta_{t} \mathrm{G}_{\mathrm{D}}\right)$.

\begin{tabular}{|c|c|c|}
\hline \multirow{3}{*}{ Residue Removal Level } & \multicolumn{2}{|l|}{$\Delta_{\mathrm{t}} \mathrm{G}_{\mathrm{D}}$} \\
\hline & CON Tillage & ALT Tillage \\
\hline & \multicolumn{2}{|c|}{$\mathrm{MgCha}{ }^{-1} \mathrm{yr}^{-1}$} \\
\hline NRR & 7.6 & 6.9 \\
\hline MRR & 6.6 & 6.3 \\
\hline HRR & 5.1 & 4.3 \\
\hline
\end{tabular}

Table 4

Comparison of field-based vs. modeled annual soil $\mathrm{N}_{2} \mathrm{O}$ emission distributions, $\Delta_{t} G_{N}^{\prime}$, for grain-only reference case under conventional tillage (NRR|CON). P10 and $\mathrm{P} 90$ are the 10 th and $90^{\text {th }}$ percentiles, respectively.

\begin{tabular}{|c|c|c|c|}
\hline \multirow[t]{3}{*}{ Data Source } & \multicolumn{3}{|c|}{$\Delta_{t} \boldsymbol{G}_{N}^{\prime}$} \\
\hline & P10 & Mean & P90 \\
\hline & \multicolumn{3}{|c|}{$\mathrm{kg} \mathrm{CO}_{2}$ eq $\mathrm{kg}^{-1}$ dry grain } \\
\hline GREET & 0.04 & 0.13 & 0.23 \\
\hline USDA-ARS REAP & 0.05 & 0.12 & 0.22 \\
\hline
\end{tabular}

production system where both grain and stover is removed (Fig. 7). Input variables involved in computing soil $\mathrm{N}_{2} \mathrm{O}$ emissions and grain yield dominate GHG emissions variability regardless of tillage practice, stover removal rate, or co-product accounting method. The variability in measured soil $\mathrm{N}_{2} \mathrm{O}$ emissions due to weather, geography, and soil type as well as measurement/sampling uncertainty is the largest contributor to variability in corn stover production GHG emissions. The percent of yearly emissions attributed to growing season $\mathrm{N}_{2} \mathrm{O}$ emissions is used to compute the yearly $\mathrm{N}_{2} \mathrm{O}$ emissions from the soil also contributes significantly to variability.
Variability in the carbon content of the products impacts soil $\mathrm{CO}_{2}$ emissions and is a major contributor to the broad distribution in stover production GHG emissions.

Net GHG emissions computed via system expansion are more sensitive to the broad distributions of the input variables due to the propagation of variability from the grain-only production reference case. Although the same key input variables are the source of the observed variability in both accounting methods, the main difference between mass allocation and system expansion sensitivities is that system expansion input variables include those from MRR fields and the same variables measured in the reference system, NRR.

\subsection{Changes to soil organic carbon}

Using the MRR|ALT case from above, we explored how hypothetical SOC changes $\left(\Delta_{\downarrow} t C_{\downarrow} S O C\right)$ under non-steady-state conditions impact net system GHG emissions relative to the NRR|CON reference scenario. Here, any SOC loss due to stover removal may be mitigated by using ALT rather than CON tillage. We assume that the theoretical upper bound of SOC change is represented as all plant carbon left on the field stored as SOC within the first $5 \mathrm{yr}$ and amortized over the $30 \mathrm{yr}$ production period. For both scenarios, the means and distributions of this upper bound are similar (Fig. 8), with broad distributions reflecting grain and stover yield variability as well as the variability in chamber-based $\mathrm{CO}_{2}$ measurements.

Using system expansion, the emissions difference between the two systems represents the potential contribution of SOC storage to field-to-farm gate emissions in a stover production system,

$\Delta_{\sigma} \Delta_{t} G_{S O C}=\Delta_{t} G_{S O C}(M R R \mid A L T)-\Delta_{t} G_{S O C}(N R R \mid C O N)$

Because distributions are similar for the stover removal case and the reference case, the mean emissions value from SOC changes is small, again with very broad distribution (Fig. 9). Specifically, soil storage of all the biomass carbon remaining on the field for the first 5 years of production reduces field-to-farm gate emissions by $\sim 15 \%$.

\section{Discussion}

\subsection{Crop yield and agricultural $\mathrm{CO}_{2}$ fluxes}

Field-based data distributions for crop yields and associated agricultural $\mathrm{CO}_{2}$ fluxes reflected trends previously reported for the 


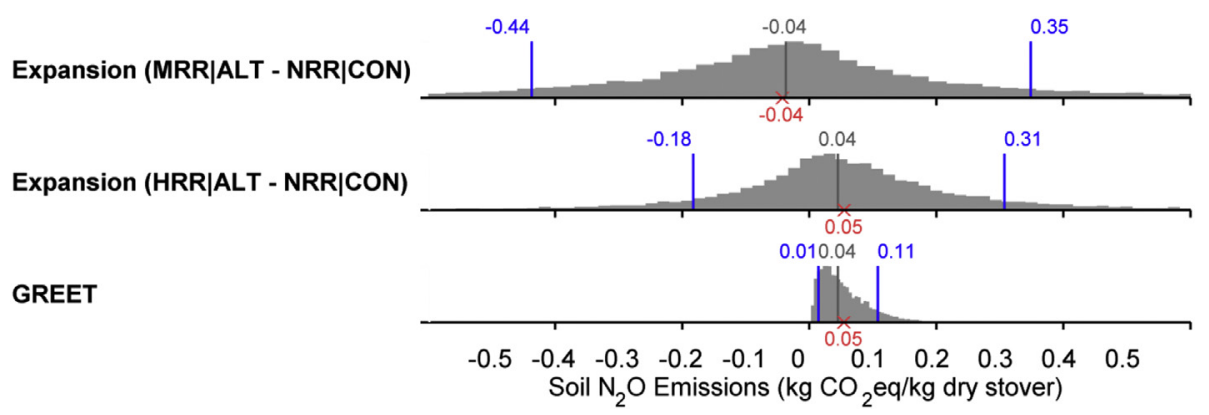




interpretation of the references to colour in this figure legend, the reader is referred to the Web version of this article.)

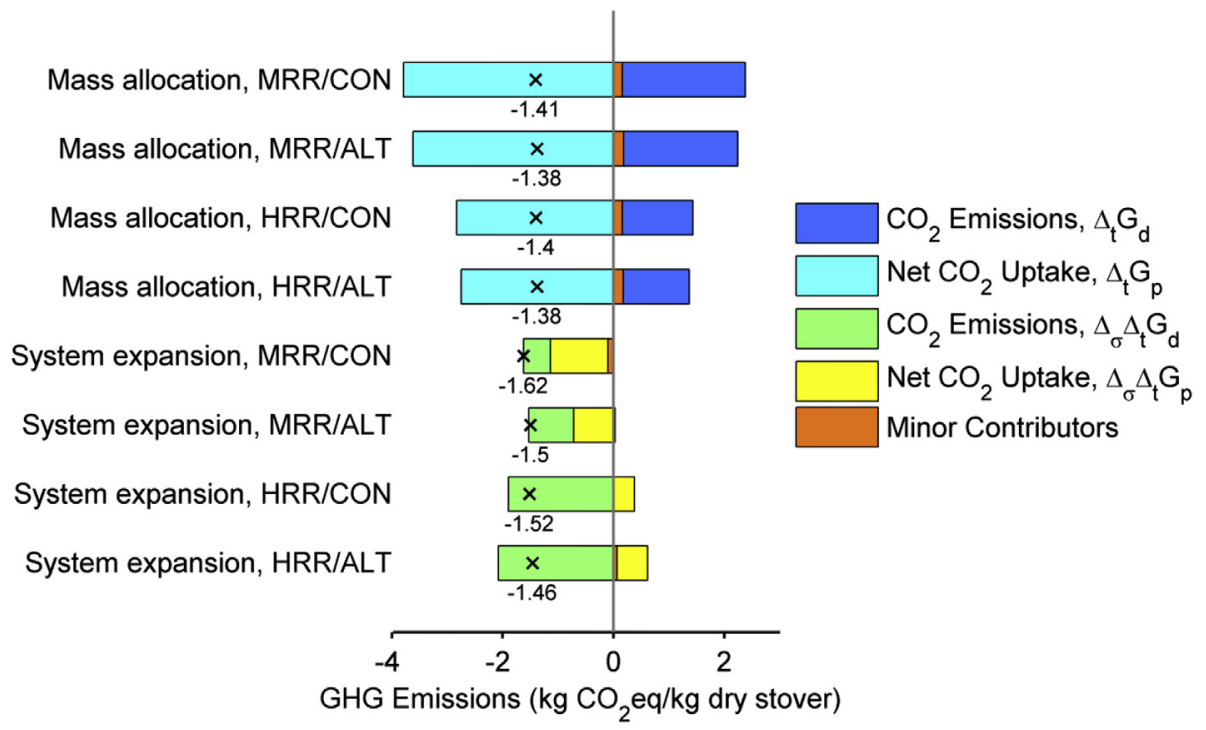

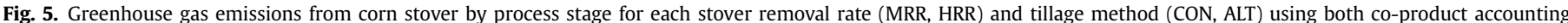
methods relative to the base case (mean values of input distributions). “ $\times$ ” symbol indicates net GHG emissions for each case. Minor contributions are detailed in Figure A5.

USDA-ARS REAP sites (Karlen et al., 2014; Jin et al., 2014). Briefly, means from data distributions show no effect of stover removal on yield. This contrasts with common LCA assumptions, such as those used in GREET, that full $\mathrm{N}$ replacement of nutrient removed in stover harvest is required to maintain corn grain yield. Field studies have shown that $\mathrm{N}$ fertilizer rates are not strongly dependent on stover removal rates as long as a minimal amount of stover is retained on the field (Coulter and Nafziger, 2008; Sindelar et al., 2012; Wortmann et al., 2016). In addition, crop $\mathrm{N}$ use efficiency in high-yield corn sites tends to increase when stover is removed, further reducing the need for additional N (Sindelar et al., 2015; Wortmann et al., 2016). Finally, grain yield does not increase with $\mathrm{N}$ fertilizer rate across sites in this dataset, likely because $\mathrm{N}$ fertilizer rates were selected at each site to optimize crop $\mathrm{N}$ uptake and minimize off-site $\mathrm{N}$ losses given local soil, climate and management conditions (Jin et al., 2014; Karlen et al., 2014).

We found here that yield is higher under CON vs ALT tillage, consistent with recent regional and global meta-analyses on tillage effects (Knapp and van der Heijden, 2015; Daigh, et al. 2018). Greater yields under CON tillage translated to higher agricultural $\mathrm{CO}_{2}$ emissions for this practice overall. Consistently broad distributions indicate that yield variability was similar across all treatment scenarios, again supported by recent meta-analyses showing no differences between CON and ALT tillage on yield variability (Knapp and van der Heijden, 2015; Daigh, et al. 2018).
Agricultural $\mathrm{CO}_{2}$ emissions due to fluxes from plant uptake and decomposition are major factors impacting net system GHG emissions. Co-accounting method calculation differences, however, affect how plant productivity and decomposition are partitioned as GHG sources or sinks (Fig. 5). Using the mass allocation method, field-to-farm gate GHG emissions are increased by $\mathrm{CO}_{2}$ emitted during decomposition $\left(\Delta_{\mathrm{t}} \mathrm{G}_{\mathrm{D}}\right)$ and decreased by plant $\mathrm{CO}_{2}$ uptake $\left(\Delta_{\mathrm{t}} G_{\mathrm{p}}\right)$, which reflects the natural carbon cycle. Using the system expansion method, however, field-to-farm gate GHG emissions are decreased by $\mathrm{CO}_{2}$ emitted during decomposition $\left(\Delta_{\sigma} \Delta_{\boldsymbol{t}} \boldsymbol{G}_{\boldsymbol{D}}\right)$ and in the HRR case, increased by $\mathrm{CO}_{2}$ uptake during photosynthesis $\left(\Delta_{\boldsymbol{\sigma}} \Delta_{\boldsymbol{t}} \boldsymbol{G}_{\boldsymbol{P}}\right)$. This counter-intuitive outcome is a result of the system expansion method where GHG emissions for each process stage are calculated as the difference in emissions per mass of corn grain between the stover removal system and the grain-only reference system (NRR $\mid \mathrm{CON}$ ). Because $\mathrm{CO}_{2}$ emissions due to biomass degradation are greater in NRR|CON than all MRR and HRR systems, the outcome is net negative agricultural $\mathrm{CO}_{2}$ emissions for the stover removal systems using system expansion. Similarly, $\mathrm{CO}_{2}$ uptake in HRR is lower per mass of corn grain grown, so $\Delta_{\sigma} \Delta_{t} G_{P}$ is a net positive for HRR cases using system expansion. Despite these specific calculation differences between co-product accounting methods, net GHG outcomes are similar using either approach (see section 4.3 below). 


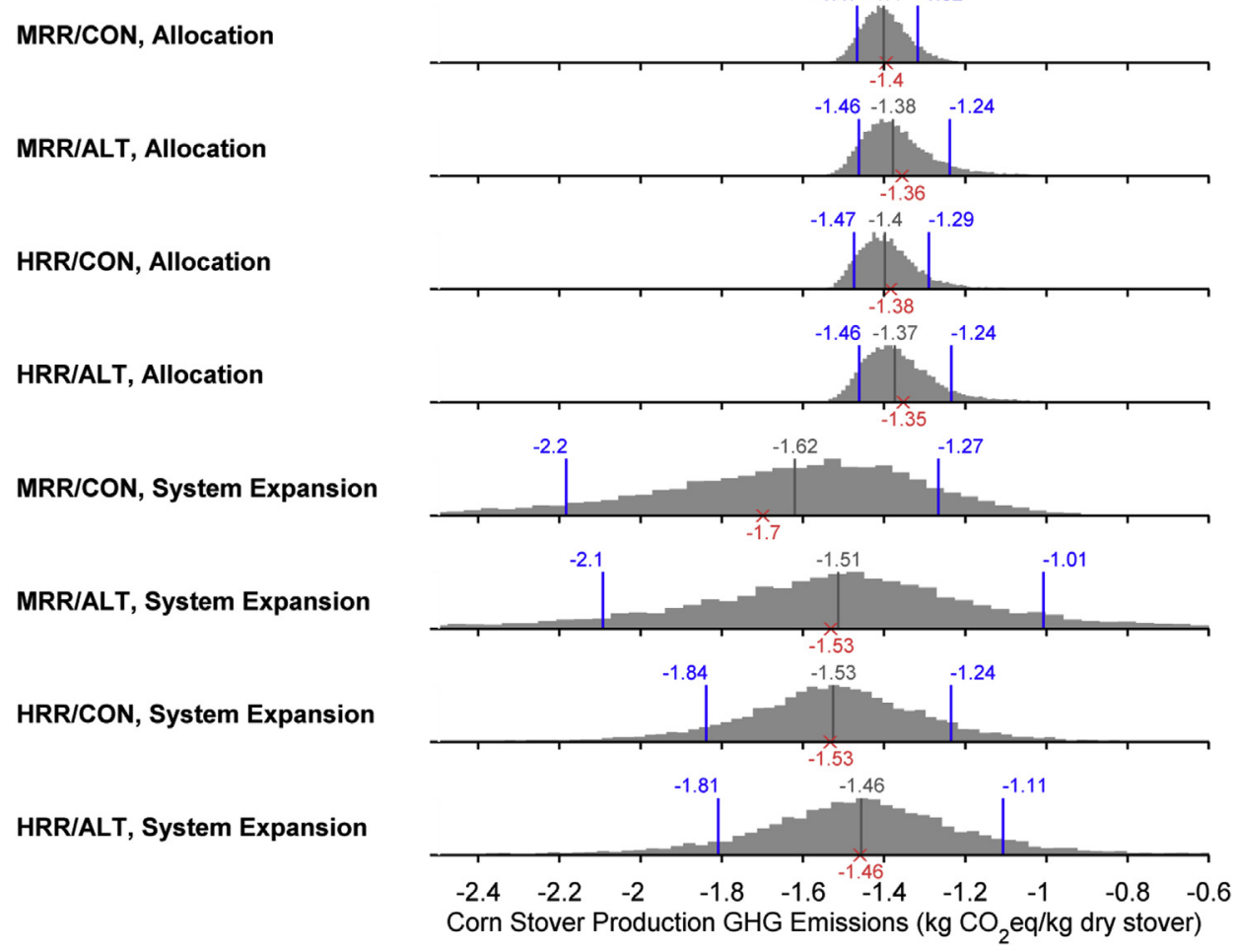

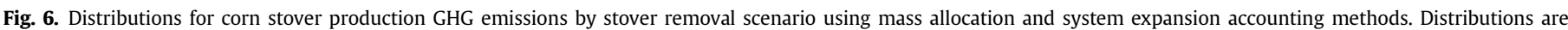


(blue). (For interpretation of the references to colour in this figure legend, the reader is referred to the Web version of this article.)

\subsection{Distributions of annual soil $\mathrm{N}_{2} \mathrm{O}$ emissions}

Overlapping data distributions for annual soil $\mathrm{N}_{2} \mathrm{O}$ emissions indicate that stover removal rates and tillage practices do not appreciably impact soil $\mathrm{N}_{2} \mathrm{O}$ emissions. The skewness of distributions are consistent with greater variability associated with the episodic nature of high emissions events (van Kessel et al., 1993; Saha et al., 2018). Somewhat higher $\mathrm{N}_{2} \mathrm{O}$ emissions under ALT, particularly when stover is retained, may result from more favorable microsite conditions for soil microbial activity compared to CON tilled soils (Jin et al., 2014).

Means from data distributions of field-based soil $\mathrm{N}_{2} \mathrm{O}$ emissions do not increase with increased $\mathrm{N}$ fertilization rate in this dataset, consistent with Jin et al. (2014). As previously discussed, sitespecific $\mathrm{N}$ fertilizer rates selected to optimize crop nutrient efficiency likely minimized risks of $\mathrm{N}$ losses, such as through $\mathrm{N}_{2} \mathrm{O}$. The absence of correlation between $\mathrm{N}$ fertilizer rate and annual $\mathrm{N}_{2} \mathrm{O}$ emissions contrasts with the IPCC Tier I assumption that soil $\mathrm{N}_{2} \mathrm{O}$ emission is a direct proportion of $\mathrm{N}$ fertilizer inputs (1\%) (IPCC, 2006).

Data distributions of annual soil $\mathrm{N}_{2} \mathrm{O}$ emissions for the grainonly reference scenario (NRR $\mid \mathrm{CON}$ ) are similar between fieldbased distributions and GREET-modeled distributions. When the stover co-product is included, however, distributions contrast sharply and highlight the fundamental differences between the GREET allocation method and the system expansion method used here. Briefly, the GREET method computes soil $\mathrm{N}_{2} \mathrm{O}$ emissions associated with stover removal similar to grain-only production. Emissions due to fertilization is the product of the volatilization rate of $\mathrm{N}$ fertilizer and the $\mathrm{N}$ fertilization rate, where $\mathrm{N}$ volatilization rate is sampled for the grain-only system distribution. For stover production, the $\mathrm{N}$ fertilization rate is a distribution computed by assuming $\mathrm{kg}$ for $\mathrm{kg}$ replacement of $\mathrm{N}$ removed due to stover harvest. In system expansion, the distribution in soil $\mathrm{N}_{2} \mathrm{O}$ emissions is built from four lognormal distributions: MRR $\mathrm{N}_{2} \mathrm{O}$ emissions per growing season, MRR $\mathrm{N}_{2} \mathrm{O}$ growing season emissions per yearly emissions, NRR $\mathrm{N}_{2} \mathrm{O}$ emissions per growing season, and $\mathrm{NRR}_{2} \mathrm{O}$ growing season emissions per yearly emissions. Using system expansion, the distributions are sampled independently so that the change in soil $\mathrm{N}_{2} \mathrm{O}$ emissions includes variability due to location as well as the marginal difference due to stover removal, leading to the Gaussian distribution shown in Fig. 4a and b. As a result, the range of the soil $\mathrm{N}_{2} \mathrm{O}$ emissions distribution is much higher in the system expansion method built from four experimentally measured distributions compared to the GREET allocation method which only multiplies one experimentally measured distribution ( $\mathrm{N}$ volatilization rate) by one idealized empirical distribution ( $\mathrm{N}$ fertilization rate).

\subsection{System GHG emissions from corn stover production}

The mean GHG emissions from corn stover production computed herein are within the range of reported literature values (McKechnie et al., 2015). The general agreement among the six management scenarios corroborates our finding that stover production emissions depend more on co-product accounting method than on management, with GHG emissions calculated with system expansion consistently lower than mass allocation ( 15\%). This is expected, as allocating by mass shifts more of the GHG emissions burden from corn grain to corn stover.

A unique aspect of the current work is the statistical sampling of key input variables to both quantify the variability in computed GHG emissions and identify the main sources of that variability. The broader data distributions using system expansion vs. mass allocation method for co-product accounting, is due to the propagation of variability from the grain-only production reference system in 


\section{A: Mass Allocation}

\section{Corn Stover Production GHG Emissions ( $\mathrm{kg} \mathrm{CO}_{2}$ eq/kg dry stover)}

\begin{tabular}{|c|c|c|}
\hline & -1.6 & -1. \\
\hline Coproduct accounting method & System expansion & Mass allocation \\
\hline $\mathrm{N}_{2} \mathrm{O}$ emissions (MRR/ALT), $\mathrm{kg} \mathrm{N} /$ ha/growing season & 0.34 & 2.5 \\
\hline Corn yield (MRR/ALT), Mg wet grain/ha/yr & 13 & 7.1 \\
\hline Fraction of annual $\mathrm{N}_{2} \mathrm{O}$ emissions occurring in growing season & $93 \%$ & $35 \%$ \\
\hline Carbon content of corn grain, $\mathrm{kg} \mathrm{C} / \mathrm{kg}$ dry corn grain & 0.44 & 0.41 \\
\hline Carbon content of corn stover, $\mathrm{kg} \mathrm{C} / \mathrm{kg}$ dry corn stover & 0.44 & 0.38 \\
\hline Nitrogen fertilization rate (MRR/ALT), $\mathrm{kg} \mathrm{N} / \mathrm{ha} / \mathrm{yr}$ & 119 & 232 \\
\hline Estimate of life cycle $\mathrm{GHG}$ emissions for $\mathrm{NH}_{4} \mathrm{NO}_{3}$ & Modified Ecoinvent & GREET 2014 \\
\hline Mass of stover removed (MRR/ALT), Mg wet stover/ha/yr & 5.5 & 2.1 \\
\hline Farm management practice for corn-and-stover production & MRR/CON & MRR/ALT \\
\hline & & \\
\hline
\end{tabular}

\section{B: System Expansion}

Corn Stover Production GHG Emissions ( $\mathrm{kg} \mathrm{CO} 2 \mathrm{eq} / \mathrm{kg}$ dry stover)



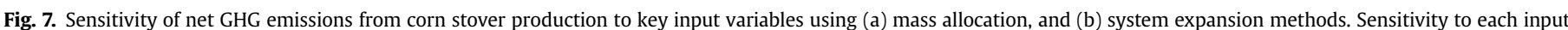
variable is assessed by holding all other input variables at their mean (base case) value. Min and max values denote p10 and p90 of the input distributions.

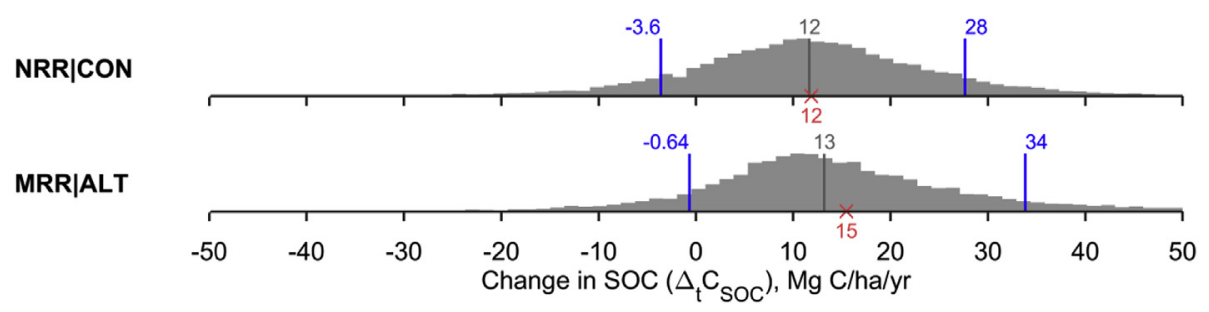

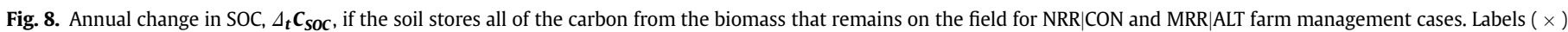

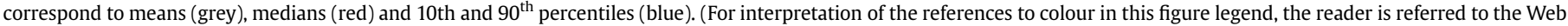
version of this article.)

MRR|ALT - LRR|CON

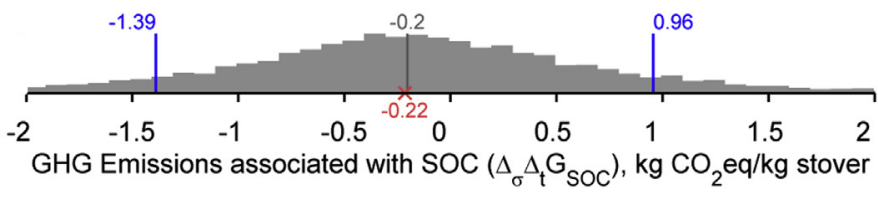

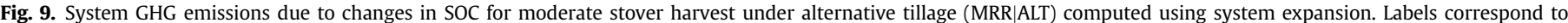

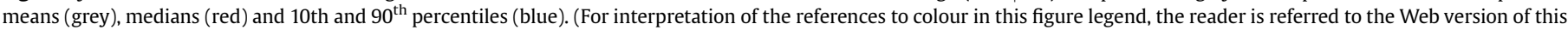
article.) 
system expansion. Overall, the mean values of system GHG emissions from stover removal scenarios are similar to grain-only reference systems, which is expected because input variable distributions all had mean values near their median values.

\subsection{Sensitivity Analyses}

The sensitivity of net GHG emissions to individual input variables depends on two factors: the relative contribution of the input variable to the overall GHG emissions and the breadth of the input distribution. Here, we find that corn stover production emissions are less sensitive to input variables under the farmer's control (i.e. $\mathrm{N}$ fertilization rate, tillage method, stover removal rate). Instead, the variability in input distributions are mainly caused by natural environmental factors for high-intensity production scenarios.

\subsection{Changes to soil organic carbon}

As with other LCAs of corn stover biofuels (Wang et al., 2012; Schmer et al., 2014b; McKechnie et al., 2015), we use a steady-state SOC assumption for the analyses above, where SOC stocks remain constant during the years of production. When evaluating the hypothetical case for non-steady-state SOC, we found that if all plant biomass remaining on the field were converted to SOC during the first five years of production under ALT tillage (as a theoretical upper bound for SOC gain), net system GHG outcomes could be reduced by an additional 15\%, though the data distribution for SOC change is quite broad. In a recent LCA of corn stover ethanol which included SOC changes simulated with the CENTURY model (Qin et al., 2018), system emissions increased as much as $25 \mathrm{~g} \mathrm{CO}_{2}$ eq $\mathrm{MJ}^{-1}$ EtOH due to SOC losses when switching from no stover removal to $30 \%$ removal under CON tillage, but were mitigated under reduced tillage $\left(15 \mathrm{~g} \mathrm{CO}_{2}\right.$ eq $\mathrm{MJ}^{-1} \mathrm{EtOH}$ ) and offset completely under no-till ( $-27 \mathrm{~g} \mathrm{CO}_{2}$ eq $\mathrm{MJ}^{-1}$ EtOH). Although CENTURY assumes that SOC gains will decrease as a function of decreasing carbon inputs, measured SOC changes in stover removal field experiments vary widely, with losses, no change, or gains reported in the U. S. Corn Belt (Follett et al., 2012) (Johnson et al., 2014) (Schmer et al., 2014a,b) (Clay et al., 2015). How SOC changes impact field-to-farm gate GHG emissions will also depend on the depth to which SOC stocks are measured. Current LCAs typically consider SOC changes in near-surface soils only (i.e. the top 20-30 cm), but the magnitude of gains and losses can decrease to near-zero when sub-surface carbon stocks (up to $150 \mathrm{~cm}$ depth) are included (Schmer et al., 2015). These variable results highlight the need for further research in quantifying the impact of farm management changes on both SOC and soil storage capacity.

\section{Conclusions}

The LCA analyses performed here using USDA-ARS REAP inventory is the first to include such a comprehensive dataset to compute field-to-farm gate GHG emissions associated with corn stover production. We find that system GHG outcomes are most sensitive to co-product accounting method, where system expansion methods result in 15\% lower emissions than commonly-used mass allocation methods. Our comparative analyses of field-based yield and soil emissions distributions as a function of stover removal rates also challenge some standard approaches and assumptions used in typical corn stover LCAs. This includes using modeled soil $\mathrm{N}_{2} \mathrm{O}$ emissions and assuming that net $\mathrm{CO}_{2}$ uptake is in balance with life-cycle biogenic carbon emissions. In this study, we find that both inputs dominate system GHG emissions and contribute the most sensitivity to GHG outcomes; thus, treating both as static inputs in typical biofuel LCAs will fail to capture the variability in system GHG emissions. Further, we find that theoretical SOC changes associated with management can reduce system GHG emissions by an additional 15\%, challenging the steadystate SOC in typical LCAs. Finally, we find that the variability in inputs due to weather, geography and soils largely overshadow the effect of farm management practices (i.e. stover removal rate, fertilization rate, tillage method) on dependent variables including soil $\mathrm{N}_{2} \mathrm{O}$ emissions and corn grain yield.

Overall, the results indicate that a moderate removal rate with reduced/no-till management results in the lowest field-to-farmgate GHG emissions associated with corn stover production, regardless of co-product accounting method. The moderate removal rate in this dataset is consistent with current stover harvesting practices being implemented by commercial-scale biorefineries in the U.S. Corn Belt. Although high removal rates in this study did not reduce grain yield or impact GHG emissions appreciably, other ecosystem benefits of stover retention, such as improved soil health and reduced soil erosion risks, will also affect producer decisions on stover management.

\section{Acknowledgments}

The authors thank Seungdo Kim for corn production data, Heather MacLean and Jon McKechnie of Savant Consulting for a thorough and thoughtful review of the work, and Aranya Venkatesh, Alessandro Faldi and Haroon Kheshgi for helpful discussions.

\section{Appendix A. Supplementary data}

Supplementary data to this article can be found online at https://doi.org/10.1016/j.jclepro.2019.03.154.

\section{References}

Archer, D.W., Johnson, J.M., 2012. Evaluating local crop residue biomass supply: economic and environmental impacts. Bioenergy Research 5, 699-712.

Argonne National Laboratory, 2014. The Greenhouse Gases, Regulated Emissions, and Energy Use in Transportation (GREET) Model. UChicago Argonne, LLC.

Canter, C.E., Dunn, J.B., Han, J., Wang, Z., Wang, M., 2016. Policy implications of allocation methods in the life cycle analysis of integrated corn and corn stover ethanol production. Bioenergy Res. 9 (1), 77-87.

Castellano, M., Mueller, K., Olk, D., Sawyer, J., Six, J., 2015. Integrating plant litter quality, soil organic matter stabilization, and the carbon saturation concept Glob. Chang. Biol. 21 (9), 3200-3209.

Clay, D., Reicks, G., Carlson, G., Moriles-Miller, J., Stone, J., Clay, S., 2015. Tillage and corn residue harvesting impact surface and subsurface carbon sequestration. J. Environ. Qual. 44, 803-809.

Coulter, J.A., Nafziger, E.D., 2008. Continuous corn response to residue management and nitrogen fertilization. Agron. J. 100 (6), 1775-1780.

Daigh, A.L.M., Dick, W.A., Helmers, M.J., Lal, R., Lauer, J.G., Nafziger, E., Pederson, C.H., Strock, J., Villamil, M., Mukherjee, A., Cruse, R., 2018. Yields and yield stability of no-till and chisel-plow fields in the Midwestern US Corn Belt. Field Crop. Res. 218, 243-253.

Del Grosso, S., White, J., Wilson, G., Vendenberg, B., Karlen, D., 2014. Introducing the GRACEnet/REAP data contribution, discovery, and retrieval system. J. Environ. Oual. 42, 1274-1280.

Follett, R.F., Vogel, K.P., Varvel, G.E., Mitchell, R.B., Kimble, J.M., 2012. Soil carbon sequestration by switchgrass and no-till maize grown for bioenergy. Bioenergy Research 4, 866-875.

Frischknecht, R., Jungbluth, N., Althaus, H.-J., Doka, G., Dones, R., Heck, T. Spielmann, M., 2005. The ecoinvent database: overview and methodological framework. Int. J. Life Cycle Assess. 10, 3-9.

Gerbrandt, K. Chu, Pei L, Simmonds, Allison, Mullins, Kimberley A MacLean, Heather L., Michael, Griffins W., Saville, Bradley A., 2016. Life cycle assessment of lignocellulosic ethanol: a review of key factors and methods affecting calculated GHG emissions and energy use. Curr. Opin. Biotechnol. $63-70$.

International Standards Organization (IESO), 2006. Environmental ManagementLife Cycle Assessment- Principles and Framework.

Iowa State Extension, 2010. Energy Conservation in Corn N Fertilization. PM 20891.

Jin, V.L., Baker, J.M., Johnson, J.M.-F., Karlen, D.L., Lehman, R., Osborne, S., 2014. Soil greenhouse gas emissions in response to corn stover removal and tillage management across the US Corn Belt. Bioenergy Research 7, 517-527. 
Johnson, J.M., Allmaras, R.R., Reicosky, D.C., 2006. Estimating source carbon from crop residues, roots and rhizodeposits using the national grain-yield database. Agron. J. 98, 622-636.

Johnson, J.M., Novak, J.M., Varvel, G.E., Stott, D.E., Osborne, S.L., Karlen, D.L. Adler, P.R., 2014. Crop residue mass needed to maintain soil organic carbon levels: can it Be determined? BioEnergy Research 7 (2), 481-490.

Karlen, D., Birrell, S., Johnson, J., Osborne, S., Schumacher, T., Varvel, G., 2014. Multilocation corn stover harvest effects on crop yields and nutrient removal. Bioenerg. Res. 7, 528-539.

Knapp, S., van der Heijden, M.G.A., 2015. A global meta-analysis of yield stability in organic and conservation agriculture. Nat. Commun. 9, 3632. https://doi.org/ 10.1038/s41467-018-05956-1.

Lehman, R.M., Osborne, S.L., 2016. Soil greenhouse gas emissions and carbon dynamics of a no-till corn-based cellulosic ethanol production system. Bioenergy Research 9 (4), 1101-1108.

McKechnie, J., Pourbafrani, M., Saville, B., MacLean, H., 2015. Exploring impacts of process technology development and regional factors on life cycle greenhouse gas emissions of corn stover ethanol. Renew. Energy 76, 726-734.

Oracle Crystal Ball. www.oracle.com, 2008.

Qin, Z., Canter, C., Dunn, J., Mueller, S., Kwon, H., Han, J., Wang, M., 2018. Land management change greatly impacts biofuels' greenhouse gas emissions. Global Change Biology Bioenergy. https://doi.org/10.1111/gcbb.12500.

Saha, D., Kemanian, A.R. Montes, F., Gall, H., Adler, P.R., Rau, B.M., 2018, Lorenz curve and Gini coefficient reveal hot spots and hot moments for nitrous oxide emissions. J. Geophys. Res. Biogeosci. 123, 193-206. https://doi.org/10.1002/ 2017JG004041.

Sanchez, S.T., Woods, J., Akhurst, M., Brander, M., O'Hare, M., Dawson, T.P. Edwards, R., Liska, A.J., Malpas, R., 2012. Accounting for indirect land-use change in the life cycle assessment of biofuel supply chains. J. R. Soc. Interface 9 (71), 1105-1119.

Schmer, M.R., Jin, V., Wienhold, B., Varvel, G., Follett, R., 2014a. Tillage and residue management effects on soil carbon and nitrogen under irrigated continuous corn. Soil Sci. Soc. Am. J. 78, 1987-1996.

Schmer, M.R., Vogel, K.P., Varvel, G.E., Follett, R.F., Mitchell, R.B., Jin, V.L., 2014b. Energy potential and greenhouse gas emissions from bioenergy cropping systems on marginally productive cropland. PLoS One 9, e89501.

Schmer, M.R., Jin, V.L., Wienhold, B.J., 2015. Sub-surface soil carbon changes affects biofuel greenhouse gas. Biomass Bioenergy 81, 31-34.

Sindelar, A.J., Lamb, J.A., Sheaffer, C.C., Jung, H.G., Rosen, C.J., 2012. Response of corn grain, cellulosic biomass, and ethanol yields to nitrogen fertilization. Agron. J. 104 (2), 363-370.

Sindelar, A.J., Coulter, J.A., Lamb, J.A., Vetsch, J.A., 2015. Nitrogen, stover, and tillage management affect nitrogen use. Agron. J. 107 (3), 843-850.

US Environmental Protection Agency, 2010. 2010 Renewable Fuel Standard Program (RFS2) Regulatory Impact Analysis. EPA-420-R-10-006. Washington, DC.

US Environmental Protection Agency, 2016. Program overview for renewable fuel standard program. Retrieved from Renewable Fuel Standard Program. www. epa.gov/renewable-fuel-standard-program. https://www.epa.gov/renewablefuel-standard-program/program-overview-renewable-fuel-standard-program.

USDA Economic Research Service, 2016, February. Corn background. Retrieved from USDA ERS Topics: Corn. http://www.ers.usda.gov/topics/crops/corn/ background.aspx.

van Kessel, C., Pennock, D.J., Farrell, R.E., 1993. Seasonal variations in denitrification and nitrous oxide evolution at the landscape scale. Soil Sci. Soc. Am. J. 57 (4), 988-995. https://doi.org/10.2136/sssaj1993.03615995005700040018x.

Wang, M., Han, J., Dunn, J.B., Cai, H., Elgowainy, A., 2012. Well-to-wheels energy use and greenhouse gas emissions of ethanol from corn, sugarcane and cellulosic biomass for US use. Environ. Res. Lett. 7 (4), 045905.

Wilhelm, W.W., Johnson, J.M.F., Karlen, D.L., Lightle, D.T., 2007. Corn stover to sustain soil organic carbon further constrains biomass supply. Agron. J. 99, 1665-1667.

International Panel on Climate Change, Working Group I, 2013. IPCC fifth assessment report. Retrieved from. https://www.ipcc.ch/report/ar5/wg1/.

Wortmann, C.S., Shapiro, C.A., Schmer, M.R., 2016. Residue harvest effects on irrigated, no-till corn yield and nitrogen response. Agron. J. 108, 384-390. https:/ doi.org/10.2134/agronj2015.0361.2016.

Zhang, Y.Z., Kendall, A., 2017. Life cycle performance of cellulosic ethanol and corn ethanol from a retrofitted dry mill corn ethanol plant. Bioenergy Res. 10 (1), 183-198. 